\title{
IPO Underpricing and Predictive Power of Board Related Corporate Governance Mechanisms: A Study of Indian IPO Market
}

\author{
Amit Kumar Singh1, Sheetal Maurya1, Amiya Kumar Mohapatra² \\ ${ }^{1}$ Department of Commerce, Delhi School of Economics, University of Delhi, New Delhi, India \\ ${ }^{2}$ Fortune Institute of International Business (FIIB), New Delhi, India \\ Email: amitipo10@gmail.com, sheetal.maurya17@gmail.com, amiyaeco125@gmail.com
}

How to cite this paper: Singh, A.K., Maurya, S. and Mohapatra, A.K. (2019) IPO Underpricing and Predictive Power of Board Related Corporate Governance Mechanisms: A Study of Indian IPO Market. Theoretical Economics Letters, 9, 2002-2018. https://doi.org/10.4236/tel.2019.96127

Received: July 13, 2019

Accepted: August 25, 2019

Published: August 28, 2019

Copyright $\odot 2019$ by author(s) and Scientific Research Publishing Inc. This work is licensed under the Creative Commons Attribution International License (CC BY 4.0).

http://creativecommons.org/licenses/by/4.0/

\begin{abstract}
Role of corporate governance indicators in IPO (Initial Public Offering) pricing is moderately researched area, however, a majority of these researches are found to be in context of other than Asian economies. Particularly, in context of Indian IPO market, only a few studies have been conducted in the past. Hence, the present study aspires to bridge this gap by examining the statistical significance of board-related corporate governance mechanisms in predicting the likelihood of IPO underpricing. This study is unique as it incorporates a new dimension of "board leadership" and examines the impact of having an independent director as the chairman of the board on IPO underpricing. Binary Logistic Regression Model is used to establish the relationship between IPO Listing gain/loss and board-related corporate governance mechanisms viz. participation of women directors on board, nature of board leadership and board independence.
\end{abstract}

\section{Keywords}

Corporate Governance, IPO Underpricing, Board Independence, Board Leadership, Gender Diversity on Board, Informational Asymmetry, Signalling Theory

\section{Introduction}

Market for initial public offerings is a well-researched area amongst the researchers' community across the globe. It is an established fact that new issue market suffers from varying nature of informational asymmetry which can be detrimental to market functioning [1]. This informational asymmetry in new is- 
sue market often takes the form of IPO underpricing. Several researches in the past have documented significantly positive initial returns and have explained this as a mechanism to signal the quality of an issue and compensation to uninformed retail investors for “winner's curse”. According to Signalling Theory, firms with good quality initial public offerings commonly resort to some sort of certification mechanisms to signal the quality of issue such as, underwriters' reputation, auditors' reputation, pre-issue venture capital backing, group affiliation, IPO grading to name a few. Researches in the past have primarily been concentrated to these conventional signalling mechanisms. Lately, corporate governance has emerged as a potential signalling mechanism. However, not many studies have been conducted to investigate the role of corporate governance mechanism in IPO underpricing, especially in context of Indian new issue market. Therefore, the present study aspires to bridge this gap by examining the statistical significance of board-related corporate governance mechanisms in predicting the likelihood of IPO underpricing. Previous researches in this area have been limited to the study of strength and direction of association between board-related governance indicators and level of underpricing. However, this study uniquely contributes to extant literature by developing a model that predicts the likelihood of IPO underpricing based on the board related governance indicators of issuing firm at the time of public offering. Therefore, a binary logistic regression model has been used in the present study. The results indicate that gender diversity on corporate board and independent board leadership are statistically significant predictors of IPO underpricing. The practical significance of these variables, however, is subject to further investigation based on larger sample size and varied variables.

This paper is organised into eight different sections; starting with the introduction to common anomaly of new issue market i.e. underpricing, various theories of IPO underpricing and alternative certification mechanisms commonly used by issuers around the globe. The second section reviews the extant literature in present area of research. The third and fourth sections of the paper list out the objectives and hypotheses of the study respectively. Section five elaborates on the data, sample size, period of study and methodology of the paper. The immediately following section presents the empirical results and analysis. The penultimate section concludes the findings of the paper. And finally, the last section discusses the limitations of this study and scope for further research in this area.

\section{Review of Literature}

Traditionally, first time issuer of equity shares relies on some sort of certification mechanisms such as underwriters' reputation, management quality, auditors' reputation, venture capital backing, group affiliation and lock-up agreement to signal the quality of their issue. And unique to Indian IPO market, sometimes issuers use IPO grading as quality indicator, however, there is no consensus on its validity and efficacy as signalling mechanism [2]. In addition to these me- 
chanisms, corporate governance practices of firms have gained considerable research interest over the past decades as researchers across the globe began to investigate its efficacy as signalling mechanism and role in IPO pricing.

The role of corporate governance indicators in IPO pricing is moderately researched area, however, a majority of these researches are found to be in context of other than Asian economies [3]. And in context of Indian IPO market only a few studies have been conducted in the past which triggers us to take the present study to enrich the extant literature and to contribute to policy making.

\subsection{Corporate Governance Practices and IPO Pricing}

Several researches in the past have found evidences that corporate governance practices of companies often add to their value, improve the firm's competitive position and provide better access to capital [4]. A company following good governance practices is also believed to look after the shareholders' interest and to maximize their wealth. In their study [5], reported that investors use corporate governance parameters as one of the shortlisting criteria while evaluating the value of a firm making an initial public offering. Hence, corporate governance parameters can be expected to have some signalling quality. However, corporate governance is a very broad concept and governance structure of an organisation is a combination of various internal and external governance mechanisms. Therefore, the present study limits its scope only to corporate board-related governance mechanisms which are a subset of overall corporate governance structure of an organisation.

\subsection{Corporate Board as Signalling Mechanism}

Board of directors is representative of shareholders' interest and is appointed by them to look after their interest. An outside director dominated board may indicate existence of a strong and effective control system [6] and can serve as a crucial signal for new issuers [7].

To study the role of board-related corporate governance measures as signalling mechanism, this study draws heavily upon the Signalling Theory and Theory of Informational Asymmetry between issuers and investors. Informational asymmetry cause issuers to rely on some kind of mechanism to signal the quality of issue to prospective investors, and signalling theory requires that signal should be observable, known in advance and difficult to imitate, to be considered as an effective signal. Since information related to corporate governance measures is disclosed by firms in their prospectus, it is easily observable and known well before the offering and hence it meets the first condition. This condition is essential to enable investors to use that information while making their investment decision; also it ensures that they get the reward for their continuous effort to stay informed and updated. The second condition requires signal to be costly and difficult to imitate. Outside directors might be reluctant to join a firm with poor fundamentals due to reputational 
cost. This potential threat to reputation of outside directors as expert decision-maker makes it difficult for poor quality firms to have reputed outside directors on board. Therefore, board-related corporate governance parameters seem to be fulfilling both core principles of signalling theory. In an important study, [8] reported the frequent turnover of senior management in financially distressed companies. Moreover, [8] found that none of these executives held similar position in listed firms for next three years post turnover.

The discussion above permits us to reasonably assume that board related corporate governance parameters may serve as a quality signal for prospective investors of a new issue because system and structure of firm at the time of initial public offering tend to remain unchanged in short run [9].

\subsection{Corporate Governance Indicators of an Effective Board}

In a study, [10] reported that board effectiveness depends on the various factors pertaining to board structure viz. board size, board independence, board leadership/CEO duality and a well-functioning audit committee. An overview of extant literature on corporate board structure and IPO underpricing have revealed that, majority of these studies have investigated into common corporate governance mechanisms like board size, board independence, and CEO duality.

More recent studies have delved into other board-related corporate governance mechanisms that might have an influence on IPO pricing, for instance, board reputation [11] \& [12], board committees and influence of CEO as founder [13] and gender diversity on board [14]. The present study uses gender diversity, board independence and nature of board leadership as corporate governance indicators to study their predictive capacity.

Although, the Indian Companies Act, 2013 has made it mandatory for all listed companies and every other public company with paid-up capital of Rs. 100 crores or more or turnover of Rs. 500 crores or more, to have at least one women director on board. It would be interesting to see if gender diversity on board amongst firms with initial public offerings can possibly be an allusion of good quality. Besides these board-related governance indicators, the present study also attempts to examine the predictive capacity of other factors related to firm, issue and ownership namely; underwriters' reputation, auditors' reputation, risk, and post issue retained ownership of promoters.

\subsection{Empirical Evidences and Findings on Board Structure and IPO Pricing}

\subsubsection{Gender Diversity: Women Directors on Board}

Researchers have put forward several beliefs and opinions on how participation of women director can be a contributory factor in corporate productivity. According to Resource Dependence Theory, each director on board provides a unique resource to organisation as they bring with them industrial/functional/ geographical knowledge, skills, experience, prestige, credibility and directors' linkages outside the organisation which are critical for firm's success. Hence, 
greater the board diversity better the access to unique resources [10].

Interestingly, participation of women directors on board as a diversity factor may have important implications. In their study, [15] reported a positive correlation between social sensitivity of group and proportion of women in group and it also enhances the collective intelligence of group. In their study, [16] documented that corporate boards with women directors are more likely to emphasize on customer satisfaction, clear communication with workers and CSR activities.

Presence of women directors on board might also provide an alternative perspective while dealing with ethical dilemmas in business. Ethics of Care Theory says, "We have obligation to exercise special care towards people with whom we have valuable close relationship". Sometimes this might lead to decisions, which contradicts with other ethical principles viz. utilitarianism, right and justice. Primarily, feminist ethicists have been responsible for advent of ethics of care theory. According to renowned psychologist Carol Gilligan, men and women deal with moral issues from different perspectives. While addressing a moral issue, men have an individualist focus on right and justice, whereas women have non-individualistic focus on care and relationship [17]. In a study, [18] documented that increased participation of women directors on board signals that company advocate women empowerment, believes in philosophy of equity and value the contribution of its women workers. These can be important signals for potential investors.

In the wake of recent changes in Indian Companies Act 2013, [14] examined the impact of gender diversity on IPO underpricing and reported a negative and insignificant impact. Gender diversity was reported as irrelevant to investors' investment decision. However, they concluded with a possibility of indirect mediating effect of gender diversity on board. In a recent study, [19] investigated the impact of gender diverse board on social and financial performance of Indian firms using a diverse sample of 54 companies. The results of the study indicate that there is no significant association of gender diversity on board with social and financial performance of select Indian firms.

\subsubsection{Board Independence}

Board independence is commonly measured by proportion of non-executive directors or independent directors on board and separation of role of CEO and chairperson. An independent board helps in reducing agency problem between management and shareholders. In a study, [20] documented that in firms with concentrated ownership, an independent board will evidently look after the interest of minority shareholders by controlling the opportunistic behaviour of controlling shareholders. It is also believed that a board dominated by outside directors improves the quality of financial disclosure and reporting [21].

In a recent study, [11] measured the board independence by proportion of non-executive director on board and reported an insignificant negative impact of board independence on IPO underpricing. Consistent with these findings, 
[14] \& [22] also reported the insignificant impact of board independence measured by proportion of independent directors on IPO underpricing.

In a study, [12] explained that board independence measured by proportion of outside directors was positively and significantly associated with underpricing. In a similar study of 101 Indonesian IPO firms, [23] examined the association between board structure, ownership and level of IPO underpricing and reported a positive and significant association between board independence and IPO underpricing.

On the contrary, based on the study of 130 IPOs listed from January 2000 to December 2004 on Euronext Paris [24], reported a statistically significant negative effect of proportion of independent directors on underpricing. Consistent with the finding of [24], [25] found a significantly negative association between proportion of independent directors and underpricing. Similarly, [26] used a cut-off of $33 \%$ of board member as non-executive directors as benchmark to measure the board independence. He found that firms having proportion of non-executive directors above the cut-off rate observed lower underpricing.

\subsubsection{Nature of Board Leadership}

The present study is unique as it incorporates a new dimension of "board leadership" to examine the impact of having an independent director as the chairman of the board on IPO underpricing. Whereas, the existing studies in related area primarily examine the impact of CEO duality on IPO underpricing.

CEO duality has been subject to considerable debate. Just like the proportion of outside directors on board, separate board leadership is also an indicator of board independence from management and allegedly brings similar advantages to firm. Majority of extant literature supports the separation of CEO-chairman position. Several researchers in the past have already documented the positive impact of CEO-chairman separation on decision making through more objective evaluation of the firm and hence improves board advice quality. For instance, [6] $\&$ [27] reported that the opportunistic behaviour of management and controlling shareholders can be controlled by separating the positions and roles of CEO and board chairman. Some studies have also pointed out the relevance of "nature of board leadership" i.e. the type of director chairing the board even if there is a clear demarcation between CEO and chairman position. For instance, [28] documented that a non-executive chairman of the board is like cherry on the top as it advances the board legitimacy.

\section{Objectives}

Present study has the following objectives:

- To study the association between gender diversity on board and IPO underpricing and its statistical significance thereof.

- To study the impact of independent board leadership on IPO underpricing and its statistical significance thereof. 
- To examine the impact of board independence on IPO underpricing and its statistical significance thereof.

- To develop a statistically significant model, using the board related corporate governance mechanisms that can successfully classify the initial public offerings as underpriced/not underpriced issues.

\section{Hypotheses Development}

To achieve the above-mentioned objectives, the present study tests the following null hypotheses:

$\mathrm{H}_{01}$ : Participation of woman directors on corporate board does not affect the likelihood of IPO underpricing, i.e., $\beta_{1}=0$.

$\mathrm{H}_{02}$ : Existence of a corporate board chaired by an independent director does not affect the likelihood of IPO underpricing, i.e., $\beta_{2}=0$.

$\mathrm{H}_{03}$ : Strength of non-executive directors and hence, board independence, does not affect the likelihood of IPO underpricing, i.e., $\beta_{3}=0$.

$\mathrm{H}_{04}$ : The predicted model is as good as intercept-only model, i.e., $\beta_{1}=\beta_{2}=\beta_{3}=$ $\beta_{4}=\beta_{5}=\beta_{6}=\beta_{7}=0$.

\section{Research Methodology and Data Collection}

\subsection{Sample and Data Collection}

The present study examines mainline Indian IPOs issued during the period of January 2011 to May 2017 and were listed on NSE. Table 1 presents the description of issues. Total 116 initial public offerings were made during the period under study out of which 10 issues failed because they were withdrawn and did not list in stock market. Hence, the sample comprised of 106 successful issues. Consistent with [24], the sample excludes the IPOs of financial services firms and banks as they are different from other businesses in two aspects, firstly, the level of opaqueness in their functioning and secondly, relatively greater role of government and other regulatory bodies. Therefore, the final sample comprises of 87 IPOs after excluding 3 IPOs for data unavailability and 16 IPOs of financial services firms/banks. The data pertaining to board-related corporate governance mechanisms is collated from the final prospectuses of firms filed with ROC which is downloaded from the official website of Securities and Exchange Board of India (SEBI).

Table 1. Description of IPOs issued during 2011-2017.

\begin{tabular}{|c|c|c|c|c|c|c|c|c|}
\hline Year & 2017 & 2016 & 2015 & 2014 & 2013 & 2012 & 2011 & Total \\
\hline Total Number of Issues (A) & 10 & 27 & 21 & 7 & 5 & 12 & 34 & 116 \\
\hline Issues Failed (B) & 0 & 1 & 0 & 2 & 2 & 2 & 3 & 10 \\
\hline Issue Succeeded $C=(A-B)$ & 10 & 26 & 21 & 5 & 3 & 10 & 31 & 106 \\
\hline Total Fund Raised (Rs. in Crores) & 727.48 & $26,372.48$ & $11,362.3$ & 1200.94 & 1283.95 & 688.31 & 5792.87 & \\
\hline
\end{tabular}

Source: Authors' calculation. 


\subsection{Statistical Model}

Since this study aims at predicting the likelihood/probability of underpricing, we take the dependent variable (IPO underpricing) as binary dichotomous variable which assumes the value 1 if an IPO is underpriced and 0 otherwise. Therefore, the binary logistic regression is the appropriate model for present study as it is used to model the probabilities of occurrence of certain event. In a binary logistic regression, dependent variable can assume only two categorical values; whereas, independent variables can be a combination of both continuous and categorical variables.

\subsubsection{Dependent Variable}

Adopting from [12] \& [29], IPO underpricing is the dependent variable used in present study which is raw return on listing day calculated as follows:

$$
\text { IPO Underpricing }(\mathrm{UP})=\frac{P_{1}-P_{0}}{P_{0}}
$$

where,

$P_{1}$ : Closing price on listing day on NSE;

$P_{0}$ : Initial offer price or issue price.

The dependent variable is transformed into binary dichotomous variable by assigning it a nominal value 1 if the IPO issuing company has listing gain based on definition above and 0 otherwise.

\subsubsection{Independent Variables}

The binary dichotomous dependent variable is regressed against measure of gender diversity on board, nature of board leadership, board independence, risk factors, underwriters' reputation, auditors' reputation and post-issue promoters' ownership. The operationalization of explanatory variables is described in Table 2.

Finally, the following model is estimated which expresses the natural log of odds as a linear combination of independent variables:

$$
\begin{aligned}
\operatorname{logit}(p)= & \ln \left(\frac{p}{1-p}\right) \\
= & \beta_{0}+\beta_{1}\left(D_{-} W D\right)+\beta_{2}(\text { ID_chairperson })+\beta_{3}\left(D_{-} \text {AboveAvgNED }\right) \\
& +\beta_{4}(\text { log_Risk })+\beta_{5}\left(D_{-} \text {UnderwriterRep }\right)+\beta_{6}\left(D_{-} \text {AuditorRep }\right) \\
& +\beta_{7}(\text { Decreased_PromOwnership })
\end{aligned}
$$

\section{Data Analysis and Results}

\subsection{Analysis of Descriptive Statistics}

Table 3 presents the descriptive statistics of overall sample. In the sample of 87 mainline IPOs under study, the initial raw return varies greatly from $-66.46 \%$ to $133.50 \%$, and the average level of underpricing is found to be $3.66 \%$. The average age of firms approaching the IPO market during sample period is approximately 18 years, with standard deviation of 13 years. Thus, it indicates great 
Table 2. Research variables and operationalization.

\begin{tabular}{|c|c|}
\hline Variable(s) & Operationalization \\
\hline \multicolumn{2}{|l|}{ Dependent Variable } \\
\hline Listing Gain (Lg) & $\begin{array}{l}\text { Binary dichotomous variable which takes a nominal value } 1 \text { if the IPO issuing company has } \\
\text { listing gain based on Equation (1) and } 0 \text { otherwise. }\end{array}$ \\
\hline \multicolumn{2}{|l|}{ Independent Variables } \\
\hline Gender Diversity (D_WD) & $\begin{array}{l}\text { Gender diversity on board is measured by presence/absence of woman director(s) on board. It is } \\
\text { transformed into a dichotomous variable which takes value } 1 \text { if woman director(s) is present on } \\
\text { board or } 0 \text { otherwise. }\end{array}$ \\
\hline Nature of Board Leadership (ID_chairperson) & $\begin{array}{l}\text { It is a dichotomous variable which takes the value } 1 \text { if the chairperson of board is an } \\
\text { independent director and } 0 \text { otherwise. }\end{array}$ \\
\hline Board Independence (D_AboveAvgNED) & $\begin{array}{l}\text { Board independence is measured by number of non-executive directors (NED) on board. It is } \\
\text { transformed into a dichotomous variable which takes the value } 1 \text { if number of NED in a firm is } \\
\text { greater than the average number of NED in sample and value } 0 \text { otherwise. }\end{array}$ \\
\hline Risk Factors (log_Risk) & $\begin{array}{l}\text { Natural log of total number of risk factors stated in final prospectus of firms, which includes } \\
\text { both internal and external risk factors. }\end{array}$ \\
\hline Underwriters' Reputation (D_UnderwriterRep) & $\begin{array}{l}\text { It is a dichotomous variable which takes the value } 1 \text { if the underwriter of the issue is amongst } \\
\text { top } 5 \text { underwriters and value } 0 \text { otherwise. }\end{array}$ \\
\hline Auditors' Reputation (D_AuditorRep) & $\begin{array}{l}\text { It is a dichotomous variable which takes the value } 1 \text { if statutory auditor of the issue is amongst } \\
\text { top } 5 \text { auditors and value } 0 \text { otherwise. }\end{array}$ \\
\hline $\begin{array}{l}\text { Post-Issue Promoters' Ownership } \\
\text { (Decreased_PromOwnership) }\end{array}$ & Total percentage decrease in promoters' ownership post public offering. \\
\hline
\end{tabular}

Source: Authors' work.

Table 3. Descriptive sample statistics.

\begin{tabular}{ccccccccc}
\hline Statistics & $\begin{array}{c}\text { Underpricing } \\
(\%)\end{array}$ & Issue Price (Rs.) & $\begin{array}{c}\text { Issue Size } \\
\text { (Rs. in Crores) }\end{array}$ & Board Size & $\begin{array}{c}\text { Number } \\
\text { of IDs }\end{array}$ & $\begin{array}{c}\text { Number of } \\
\text { NED \& NID }\end{array}$ & $\begin{array}{c}\text { Women } \\
\text { Director }\end{array}$ & Firm's Age \\
\hline N & 87 & 87 & 87 & 87 & 87 & 87 & 87 & 87 \\
Mean & $3.66^{\mathrm{a}}$ & 243.06 & 418.61 & 7.79 & 3.87 & 1.44 & 0.95 & 17.99 \\
Median & 3.79 & 178 & 219.58 & 8 & 4 & 1 & 1 & 15 \\
Mode & 7.35 & 210 & $60^{\mathrm{b}}$ & 8 & 3 & 0 & 1 & $5^{\mathrm{b}}$ \\
Std. Deviation & 37.471 & 216.87 & 558.28 & 2.041 & 1.076 & 1.255 & 0.761 & 13.293 \\
Minimum & -66.46 & 10 & 23 & 4 & 2 & 0 & 0 & 3 \\
Maximum & 133.50 & 1050 & 4156 & 12 & 6 & 4 & 4 & 63 \\
Sum & 891.27 & 21146 & 36419 & 678 & 337 & 125 & 83 & 1565
\end{tabular}

Source: Authors' calculation. Notes: a) Indicates the geometric mean of initial listing gain/loss calculated by adding a constant of 100 to each observation and deducting the same from the resultant geometric mean. b) Multiple modes exist. The smallest value is shown. Note: IDs indicates independent directors. NED \& NID indicates non-executive directors who are not independent directors. Firm's age denotes to the number of years from date of incorporation to date of listing.

variation in the age of firms approaching the IPO market. Statistics also indicate a great variation in issue prices and issue size of sample IPOs, with average issue price of Rs. 243 and average issue size Rs. 418.61 crores approximately. Approximately, a total of Rs. 36,419 crores were raised during sample period through initial public offerings. It is observed that the average size of corporate 
board in sample firms is approximately 8 directors and the number of directors is normally distributed across sample firms. Board size ranges from 4 to $12 \mathrm{di}$ rectors, which is well within the prescribed limit ${ }^{1}$. Descriptive statistics of number of independent directors indicates approximately $50 \%$ of board of sample firms is comprised of independent directors which is merely sufficient to meet regulatory requirements ${ }^{2}$.

Number of woman directors is normally distributed across sample firms. Moreover, only $12.24 \%$ of directors are woman, which clearly indicates lack of gender diversity on corporate board.

Table 4 presents the descriptive sample statistics of two mutually exclusive groups of IPOs with listing gain and IPOs with listing loss. In a sample 87 IPOs, majority (50 IPOs i.e. 57.47\%) are underpriced. There is no significant difference

Table 4. Grouped sample characteristics.

\begin{tabular}{|c|c|c|c|c|c|c|c|c|c|}
\hline \multicolumn{2}{|c|}{ Groups } & \multirow{2}{*}{$\begin{array}{c}\text { Board Size } \\
37\end{array}$} & \multirow{2}{*}{$\begin{array}{c}\begin{array}{c}\text { Woman } \\
\text { Director }\end{array} \\
37\end{array}$} & \multirow{2}{*}{$\begin{array}{c}\begin{array}{c}\text { Number } \\
\text { of IDs }\end{array} \\
37\end{array}$} & \multirow{2}{*}{$\begin{array}{c}\text { No. of NED } \\
\text { \& NID } \\
37\end{array}$} & \multirow{2}{*}{$\begin{array}{c}\text { Firm's Age } \\
\text { (in Years) } \\
37\end{array}$} & \multirow{2}{*}{$\begin{array}{c}\text { Issue Size } \\
\text { (Rs. in } \\
\text { Crores) } \\
37\end{array}$} & \multirow{2}{*}{$\begin{array}{c}\begin{array}{c}\text { Issue Price } \\
\text { (Rs.) }\end{array} \\
37\end{array}$} & \multirow{2}{*}{$\begin{array}{c}\begin{array}{c}\text { Book Value of } \\
\text { Total Asset }\end{array} \\
\text { (Rs. in Crores) } \\
37\end{array}$} \\
\hline Not & $\mathrm{N}$ & & & & & & & & \\
\hline \multirow{6}{*}{ Under-Priced } & Mean & 7.76 & 1.03 & 3.89 & 1.35 & 17.38 & 372.56 & 204.54 & 1116.8529 \\
\hline & Median & 8 & 1 & 4 & 1 & 15 & 200 & 135 & 395.165 \\
\hline & Sum & 287 & 38 & 144 & 50 & 643 & 13785 & 7568 & $41,323.56$ \\
\hline & Minimum & 5 & 0 & 3 & 0 & 4 & 25 & 10 & 14.54 \\
\hline & Maximum & 12 & 4 & 6 & 4 & 63 & 4156 & 710 & $18,185.72$ \\
\hline & Std. Deviation & 2.019 & 0.799 & 1.048 & 1.317 & 13.531 & 705.852 & 190.50 & 2989.4611 \\
\hline \multirow[t]{7}{*}{ Under-Priced } & $\mathrm{N}$ & 50 & 50 & 50 & 50 & 50 & 50 & 50 & 50 \\
\hline & Mean & 7.82 & 0.90 & 3.86 & 1.50 & 18.44 & 452.69 & 271.56 & 1979.7106 \\
\hline & Median & 8 & 1 & 4 & 1 & 15 & 375.93 & 195.50 & 602.3860 \\
\hline & Sum & 391 & 45 & 193 & 75 & 922 & 22634 & 13578 & $98,985.53$ \\
\hline & Minimum & 4 & 0 & 2 & 0 & 3 & 23 & 10 & 22.21 \\
\hline & Maximum & 12 & 3 & 6 & 4 & 60 & 1870 & 1050 & $36,097.54$ \\
\hline & Std. Deviation & 2.077 & 0.735 & 1.107 & 1.216 & 13.234 & 422.123 & 232.239 & 5258.1375 \\
\hline Total & $\mathrm{N}$ & 87 & 87 & 87 & 87 & 87 & 87 & 87 & 87 \\
\hline
\end{tabular}

Source: Authors' calculation. Notes: 1) IDs indicates independent directors. NED \& NID indicates non-executive directors who are not independent directors. Firm's age denotes to the number of years from date of incorporation to date of listing. 2) The grouped descriptive statistics in Table 4 are calculated using the raw values of various variables pertaining to issues made by firms in final sample. These variables were then transformed for the purpose of logistic regression model.

\footnotetext{
${ }^{1}$ As per companies Act 2013, the minimum no. of directors for a public company is 3, for a private company is 2 and for one-person company is 1 . The maximum no. of directors on board is limited to 15 which may be increased by passing a special resolution.

${ }^{2}$ SEBI's Clause 49 of listing agreement requires that at least $50 \%$ of board should be comprised of non-executive directors with at least 1-woman director on board. If the chairperson of the board is non-executive director, then at least $1 / 3^{\text {rd }}$ of the board should be comprised of independent director. In the absence of regular non-executive chairperson or in case non-executive chairperson is promoter of the company or in any way related to promoters of the company, then at least half of the board should be comprised of independent directors.
} 
in board size of underpriced IPO firms and overpriced IPO firms $[\mathrm{t}(85)=-0.142$, $\mathrm{p}=0.887]$. Moreover, there is no distinctive characteristic between the two groups in terms of board composition because the two groups do not differ significantly w.r.t. gender diversity $[\mathrm{t}(85)=0.768, \mathrm{p}=0.445]$; number of independent directors on board $[\mathrm{t}(85)=0.136, \mathrm{p}=0.892]$; and number of non-executive and non-independent directors $[\mathrm{t}(85)=-0.544, \mathrm{p}=0.588]$. The average age of firms in the two groups is not significantly different. An initial inspection of descriptive statistics indicates that the issue price and issue size of underpriced IPOs are greater than the overpriced IPOs, however, this difference is not statistically significant for either of two variables. Although the minimum issue price is the same for IPOs of both groups, the maximum issue price is much higher for underpriced IPOs. Likewise, average book value of total assets, which is taken as an indicator of firm size, is higher amongst the underpriced IPOs but it is not significantly higher than those of overpriced IPOs $[t(85)=-0.896, p=0.373]$.

\subsection{Results of Logistic Regression}

\subsubsection{Beginning Block/Intercept-Only Model}

The beginning block model includes only the intercept and does not include any predictor variable. It randomly assumes that all the cases in dataset shall be "success", i.e. underpriced IPOs in present case. Thus, Classification Table 5 indicates that even a model which does not include any of predictor variable, can still predict the $57.5 \%$ of total cases correctly. This percentage should increase, for our model in Equation 2 to be a significant model.

The intercept-only model in "variables in equation" Table 6 can be expressed as $\ln$ (odds) $=0.301$. Hence, the predicted odds of an IPO being underpriced are 1.351 .

\subsubsection{The Estimated Model}

The estimated model is expressed by Equation 2; and it includes the board Table 5. Classification table of intercept only model.

\begin{tabular}{|c|c|c|c|c|}
\hline & \multirow{3}{*}{ Observed } & \multicolumn{3}{|c|}{ Predicted } \\
\hline & & \multicolumn{2}{|c|}{ D_Underpricing } & \multirow{2}{*}{$\begin{array}{c}\text { Percentage } \\
\text { Correct }\end{array}$} \\
\hline & & Not Underpriced & Underpriced & \\
\hline \multirow{3}{*}{ Step 0} & Not Underpriced & 0 & 37 & .0 \\
\hline & D_Underpricing & 0 & 50 & 100.0 \\
\hline & Overall Percentage & & & 57.5 \\
\hline
\end{tabular}

Source: Authors' calculation. Note: constant is included in the model. The cut value is 0.5 .

Table 6. Variables in the equation for intercept only model.

\begin{tabular}{cccccccc}
\hline & & B & S.E. & Wald & df & Sig. & Exp(B) \\
\hline \multirow{2}{*}{ Step 0 } & Constant & 0.301 & 0.217 & 1.928 & 1 & 0.165 & 1.351 \\
\hline
\end{tabular}

Source: Authors' calculation. 
related corporate governance mechanisms and other control variables as predictor variables. The "omnibus tests of model coefficients" in Table 7 uses the chi-square statistics to test the null hypothesis that predictor variables in our model have not significantly increased our ability to predict whether an IPO shall be underpriced or not. The test result in Table 7 indicates that the model is significant at $10 \%$ significance level.

The Model summary in Table 8 gives the explained variance. Both Cox \& Snell $\mathrm{R}^{2}(13.3 \%)$ and Nagelkerke $\mathrm{R}^{2}(17.9 \%)$ are pseudo R-square (and shall have lower values than in multiple regression). The Hosmer and Lemeshow test the null hypothesis that the prediction made by the estimated model fit perfectly with observed group membership. The insignificance of Hosmer and Lemeshow Test in Table 8 indicates that there is good fit between the data and the estimated model, and that null hypothesis cannot be rejected.

Table 9 shows that classification rule allows the model to correctly classify $80 \%$ (i.e. 40/50) of cases where the predicted event (i.e. IPO underpricing) was observed. This is called "sensitivity" of prediction, which is percentage of occurrences correctly predicted, calculated by $\mathrm{P}$ (correct/occurrence of event). The "specificity" of the model prediction is $54.05 \%$ (i.e. 20/37) which indicates the

Table 7. Omnibus tests of model coefficients.

\begin{tabular}{cccc}
\hline & Chi-square & df & Sig. \\
\hline Estimated Model & 12.417 & 7 & 0.088
\end{tabular}

Source: Authors' calculation.

Table 8. Model summary.

\begin{tabular}{|c|c|c|c|}
\hline Step & -2 Log likelihood & Cox \& Snell R Square & Nagelkerke R Square \\
\hline \multirow[t]{2}{*}{1} & $106.241^{\mathrm{a}}$ & 0.133 & 0.179 \\
\hline & \multicolumn{3}{|c|}{ Hosmer and Lemeshow Test } \\
\hline Step & Chi-Square & df & Sig. \\
\hline 1 & 4.072 & 8 & 0.851 \\
\hline
\end{tabular}

Source: Authors' calculation.

Table 9. Classification table of estimated model.

\begin{tabular}{ccccc}
\hline \multirow{2}{*}{ Observed } & \multicolumn{3}{c}{ Predicted } \\
\cline { 3 - 4 } & \multicolumn{2}{c}{ D_Underpricing } & \\
\cline { 3 - 4 } & Not Underpriced & 20 & 17 & 54.1 \\
\hline \multirow{2}{*}{ D_Underpricing } & Not Underpriced & Underpriced & 80.0 \\
\cline { 3 - 4 } Onerall Percentage & Underpriced & 10 & 40 & 69.0 \\
\hline
\end{tabular}

Source: Authors' calculation. Note: the cut value is 0.5 i.e. better than an even chance. The cut value is used to classify subjects. If the estimated probability is greater than 0.5 the test classifies the event as occurring (in this case "underpriced") and not occurring otherwise (in this case "not underpriced"). 
percentage of non-occurrence of event that is correctly predicted by the model and is calculated as $\mathrm{P}$ (correct/non-occurrence of event). Overall, the model correctly predicts 60 out of 87 (i.e. overall accuracy of 69\%). The overall accuracy of prediction has improved from $57.5 \%$ (in block 0 , Table 5.5 ) to $69 \%$ due to inclusion of predictor variables in model.

Focusing on the error rates of model prediction, the percentage of "false positive" is $29.82 \%$. The classification rule predicts that total 57 IPOs as underpriced and that prediction was wrong 17 times, which is approximately $29.82 \%$ of total predictions where the IPO was classified as underpriced by the model. On the other hand, the percentage of "false negative", that is, number of wrong predictions out of total predicted cases of "not underpriced" IPOs, is $33.33 \%$ (i.e. 10/30).

The classification table indicates that the "sensitivity" of the model is higher than its "specificity", which means the model can more accurately predict the cases of underpriced IPOs than the cases of "not underpriced" IPOs.

The "Variables in Equation" in Table 10 shows the logistic regression coefficients, Wald statistics, and odds ratio for each of the predictor variable. Wald Chi-square statistics indicate the unique contribution of each predictor variable, holding other variables constant. The test result shows that, amongst the board related corporate governance variables, board diversity $(\mathrm{p}=0.089)$ and nature of board leadership ( $\mathrm{p}=0.091$ ) added significantly to the estimated model at $10 \%$ level of significance. However, strength of non-executive directors on board did not add significantly $(\mathrm{p}=0.146)$. Amongst other explanatory variables taken in the model, underwriters' reputation and post-issue promoters' ownership are also found to be significant at $10 \%$ level of significance.

\subsubsection{Statistical Interpretations}

- Odds of getting IPO underpricing (or listing gain) for firms having woman director on their board is 2.839 times greater than firms without the participation

Table 10. Variables in the equation of estimated model.

\begin{tabular}{|c|c|c|c|c|c|c|c|c|c|c|}
\hline \multirow[t]{2}{*}{ Variables } & \multirow[t]{2}{*}{ B } & \multirow[t]{2}{*}{ S.E. } & \multirow[t]{2}{*}{ Wald } & \multirow[t]{2}{*}{ df } & \multirow[t]{2}{*}{ Sig. } & \multirow[t]{2}{*}{ Decision } & \multirow{2}{*}{$\begin{array}{l}\text { Nature of } \\
\text { Relationship }\end{array}$} & \multirow{2}{*}{$\begin{array}{l}\text { Odds Ratio } \\
\operatorname{Exp}(\mathrm{B})\end{array}$} & \multicolumn{2}{|c|}{$\begin{array}{c}95 \% \text { C.I. } \\
\text { for } \operatorname{EXP(B)}\end{array}$} \\
\hline & & & & & & & & & Lower & Upper \\
\hline D_WD (1) & 1.044 & 0.614 & 2.893 & 1 & $0.089^{*}$ & Significant at $10 \%$ & Positive & 2.839 & 0.853 & 9.450 \\
\hline ID_chairperson (1) & -1.277 & 0.755 & 2.856 & 1 & $0.091^{*}$ & Significant at $10 \%$ & Negative & 0.279 & 0.063 & 1.226 \\
\hline D_AboveAvgNED (1) & -0.821 & 0.564 & 2.116 & 1 & 0.146 & Insignificant & Negative & 0.440 & 0.146 & 1.330 \\
\hline log_Risk & 1.590 & 1.155 & 1.895 & 1 & 0.169 & Insignificant & Positive & 4.904 & 0.510 & 47.180 \\
\hline D_UnderwriterRep (1) & -0.942 & 0.552 & 2.907 & 1 & $0.088^{*}$ & Significant at $10 \%$ & Negative & 0.390 & 0.132 & 1.151 \\
\hline D_AuditorRep (1) & -0.034 & 0.802 & 0.002 & 1 & 0.966 & Insignificant & Negative & 0.966 & 0.201 & 4.650 \\
\hline Decreased_PromOwnership & 0.047 & 0.027 & 3.177 & 1 & $0.075^{*}$ & Significant at $10 \%$ & Positive & 1.048 & 0.995 & 1.104 \\
\hline Constant & -5.072 & 5.105 & 0.987 & 1 & 0.321 & Insignificant & - & 0.006 & & \\
\hline
\end{tabular}

Source: Authors' calculation. Notes: 1) variable(s) entered on step 1: D_WD, ID_chairperson, D_AboveAvgNED, log_Risk, D_UnderwriterRep, D_AuditorRep, Decreased_PromOwnership. 2) p-values with “*” indicates statistical significance of predictor variable at $10 \%$ level of significance. 
of woman director on board. Meaning thereby, presence of woman director on board increases the likelihood (or probability) of IPO underpricing.

- The negative $\beta$ sign of ID chairperson indicates a negative association with IPO underpricing. Odds of IPO underpricing in firms whose chairperson is an independent director is only 0.279 times those of whose chairperson is other than an independent director. In other words, presence of independent director as the chairperson of the board reduces the likelihood (or probability) of IPO underpricing.

- Similarly, likelihood of IPO underpricing decreases with presence of reputed underwriters. Because the odds of underpricing for IPOs which was managed by top 5 underwriters is only 0.39 times those of managed by less reputed underwriters.

- It is also observed that greater post-issue decline in promoters' ownership is a distinguishing characteristic amongst the underpriced IPOs. In other words, the odds of IPO underpricing increases with post-issue decrease in promoters' ownership. A unit decrease in promoters' ownership cause probability of listing gain (p) to increase by factor of 1.048 (or $4.8 \%$ ). This may not necessarily be against the principle of good governance as dilution of promoters' holding within the regulatory limit reduces their controlling position in decision making. Hence, a decline in promoters' ownership can be associated with increased participation of shareholders.

The following equation of fitted model can finally be obtained by substituting the values of partial slope coefficients and intercept term:

$$
\begin{aligned}
\operatorname{logit}(p)= & \ln \left(\frac{p}{1-p}\right) \\
= & -5.072+1.044\left(D \_W D\right)-1.277(\text { ID_chairperson }) \\
& -0.821\left(D \_ \text {_AboveAvgNED }\right)+1.59(\log \text { risk }) \\
& -0.942(\text { D_UnderwriterRep })-0.034(\text { D_AuditorRep }) \\
& +0.047(\text { Decreased_PromOwnership })
\end{aligned}
$$

\section{Conclusions}

The present study uses the logistic regression to develop a model that can predict the probability of occurrence or non-occurrence of IPO underpricing based on board-related corporate governance mechanisms. A test of full model versus a model with intercept only is statistically significant $\left[\chi^{2}(7, \mathrm{~N}=87)=12.417, \mathrm{p}<\right.$ 0.10]. The predicted model has a high degree of "sensitivity" and "false positive error", which means the model can more accurately predict the cases of underpriced IPOs than the cases of "not underpriced" IPOs. The overall success rate of model is found to be $69 \%$. Employing a 0.10 criterion of statistical significance, gender diversity (i.e. presence of woman director on board) and nature of board leadership (demonstrated by independent chairperson) are found to be statistically significant predictor amongst the board related corporate governance mechanisms. The statistical significance of these corporate governance mechanisms 
supports our initial supposition that select corporate governance variables possess some signalling capacity and hence, may contribute significantly in prediction of IPO underpricing. The present study reports that presence of woman director on board increases the likelihood (or probability) of IPO underpricing. Contrary to this, presence of independent director as the chairperson of the board reduces the likelihood (or probability) of IPO underpricing. However, the number of non-executive directors as a measure of board independence has an insignificantly negative impact on likelihood of occurrence of IPO underpricing.

To conclude, although the present study conveys that, board-related corporate governance mechanisms viz. gender diversity and nature of board leadership may be statistically significant predictors of IPO underpricing, their practical significance is subject to further investigation based on larger sample size and varied variables.

\section{Limitation and Scope for Future Research}

A sample size of 87 mainline IPOs limits our ability to incorporate more indicators of corporate governance in our model as independent variables. Further, scope of present study is limited to corporate board-related governance mechanisms only; which is merely a subset of overall corporate governance structure of the organisation. Future research can be directed towards investigation into other board-related corporate governance indicators such as, composition of board committees and nature of leadership of board committees.

\section{Conflicts of Interest}

The authors declare no conflicts of interest regarding the publication of this paper.

\section{References}

[1] Akerlof, G. (1970) The Market for Lemons: Quality Uncertainty and the Market Mechanism. The Quarterly Journal of Economics, 84, 488-500. https://doi.org/10.2307/1879431

[2] Maurya, S. (2017) IPO Grading in India: A Review of Literature. In: Singh, A.K., Ed., Emerging Issues and Challenges in Finance, Galgotia Publishing Company, New Delhi, 55-78.

[3] Yong, O. (2007) A Review of IPO Research in Asia: What's Next? Pacific-Basin Finance Journal, 15, 253-275. https://doi.org/10.1016/j.pacfin.2006.09.001

[4] Shleifer, A. and Vishny, R.W. (1997) A Survey of Corporate Governance. The Journal of Finance, 52, 737-783. https://doi.org/10.1111/j.1540-6261.1997.tb04820.x

[5] Sanders, W.M. and Boivie, S. (2004) Sorting Things Out: Valuation of New Firms in Uncertain Markets. Strategic Management Journal, 25, 167-186. https://doi.org/10.1002/smj.370

[6] Fama, E.F. and Jensen, M.C. (1983) Separation of Ownership and Control. Journal of Law and Economics, 26, 301-325. https://doi.org/10.1086/467037

[7] Gompers, P.A. (1995) Optimal Investment, Monitoring, and the Staging of Venture Capital. Journal of Finance, 50, 1461-1489. 
https://doi.org/10.1111/j.1540-6261.1995.tb05185.x

[8] Gilson, S.C. (1989) Management Turnover and Financial Distress. Journal of Financial Economics, 25, 241-262. https://doi.org/10.1016/0304-405X(89)90083-4

[9] Welbourne, T.M. and Andrews, A.O. (1996) Predicting the Performance of Initial Public Offerings: Should Human Resource Management Be in the Equation? Academy of Management Journal, 39, 891-919. https://doi.org/10.2307/256716

[10] Johnson, J.L., Daily, C.M. and Ellstrand, A.E. (1996) Board of Directors: A Review and Research Agenda. Journal of Management, 22, 409-438. https://doi.org/10.1177/014920639602200303

[11] Yatim, P. (2011) Underpricing and Board Structures: An Investigation of Malaysian Initial Public Offerings. Asian Academy of Management Journal of Accounting and Finance, 7, 73-93.

[12] Certo, S.T., Daily, C.M. and Dalton, D.R. (2001) Signaling Firm Value through Board Structure: An Investigation of Initial Public Offerings. Entrepreneurship Theory \& Practice, 26, 33-50. https://doi.org/10.1177/104225870102600202

[13] Hearn, B. (2011) The Impact of Corporate Governance Measures on the Performance of West African IPO Firms. Emerging Markets Review, 12, 130-151. https://doi.org/10.1016/j.ememar.2011.02.004

[14] Handa, R. and Singh, B. (2015) Women Directors and IPO Underpricing: Evidence from Indian Markets. Gender in Management: An International Journal, 30, 186-205. https://doi.org/10.1108/GM-02-2014-0011

[15] Woolley, A.W., Chabris, C.F., Pentland, A., Hashmi, N. and Malone, T. (2010) Collective Intelligence: Number of Women Linked to Effectiveness in Solving Difficult Problems. Science Daily, 2, 686-688. https://doi.org/10.1126/science.1193147

[16] Brown, D., Brown, D.L. and Anastasopoulos, V. (2002) Women on Board: Not Just the Right Thing, But the Bright Thing. Conference Board of Canada, Ottawa.

[17] Velasquez, M.G. (2014) Ethical Principles in Business. In: Velasquez, M.G., Ed., Business Ethics: Concepts and Cases, Seventh Edition, Pearson Education Limited, London, 126-130.

[18] Bilimoria, D. (2000) Building the Business Case for Women Corporate Directors. In: Bruke, R. and Mattis, M.C., Eds., Women on Corporate Boards of Directors: International Challenges and Opportunities, Kluwer Academic Publishers, Dordrecht, 25-40. https://doi.org/10.1007/978-90-481-3401-4_3

[19] Sanan, N.K. (2016) Board Gender Diversity, Financial and Social Performance of Indian Firms. Vision, 20, 361-367. https://doi.org/10.1177/0972262916673006

[20] Anderson, R.C. and Reeb, D.M. (2003) Founding-Family Ownership and Firm Performance: Evidence from S\&P 500. The Journal of Finance, 61, 1301-1328. https://doi.org/10.1111/1540-6261.00567

[21] Vafeas, N. (2000) Board Structure and the Informativeness of Earnings. Journal of Accounting and Public Policy, 19, 139-160. https://doi.org/10.1016/S0278-4254(00)00006-5

[22] Singh, A.K. and Maurya, S. (2018) Corporate Governance, Ownership Structure, and IPO Underpricing: Evidence from the Indian New Issue Market. Indian Journal of Research in Capital Markets, 5, 7-24. https://doi.org/10.17010/ijrcm/2018/v5/i1/122905

[23] Darmadi, S. and Gunawan, R. (2013) Underpricing, Board Structure, and Ownership: An Empirical Examination of Indonesian IPO Firms. Managerial Finance, 39, 181-200. https://doi.org/10.1108/03074351311294016 
[24] Mnif, A. (2009) Board of Directors and the Pricing of Initial Public Offerings (IPOs): Does the Existence of a Properly Structured Board Matter? Evidence from France. La place de la dimension europëenne dans la Comptabilite' Controle Audit. Strasbourg, France.

[25] Lin, C.P. and Chuang, K. (2011) Principal-Principal Conflicts and IPO Pricing in an Emerging Economy. Corporate Governance: An International Review, 19, 585-600. https://doi.org/10.1111/j.1467-8683.2011.00870.x

[26] Filatotchev, I. and Bishop, K. (2002) Board Composition, Share Ownership, and "Underpricing" of U.K. IPO Firms. Strategic Management Journal, 23, 941-955. https://doi.org/10.1002/smj.269

[27] Jensen, M.C. and Meckling, W.H. (1976) Theory of the Firm: Managerial Behaviour, Agency Costs and Ownership Structure. Journal of Financial Economics, 3, 305-360. https://doi.org/10.1016/0304-405X(76)90026-X

[28] Hung, H. (1998) A Typology of the Theories of the Roles of Governing Boards. Corporate Governance: An international Review, 6, 101-111. https://doi.org/10.1111/1467-8683.00089

[29] Arthurs, J.D., Hoskisson, R.E., Busenitz, L.W. and Johnson, R.A. (2008) Managerial Agents Watching Other Agents: Multiple Agency Conflicts Regarding Underpricing in IPO Firms. Academy of Management Journal, 51, 277-294.

https://doi.org/10.5465/amj.2008.31767256 